\title{
The Functionality of Book-to-Market Ratio in Chinese Markets
}

\author{
Larry $\mathrm{Li}^{1}$, Adela McMurray ${ }^{1} \&$ Bo Liu ${ }^{2}$ \\ ${ }^{1}$ RMIT University, Melbourne, Australia \\ ${ }^{2}$ Dongguan Industrial Investment Holding Group, Guangdong, China \\ Correspondence: Larry Li, RMIT University, Melbourne, VIC 3000, Australia.
}

Received: September 28, 2018

Accepted: November 13, 2018

Online Published: November 29, 2018

doi:10.20849/iref.v2i2.514

URL: https://doi.org/10.20849/iref.v2i2.514

\begin{abstract}
We investigate the question whether the book to market ratio acts as a "risk-based" or "mispricing-based" proxy for share price formation in Chinese markets. We find that a strong relationship is observed between the firms' book to market ratio and stock returns both in current and following years, while we cannot find a steady relationship between market leverage ratio and stock returns. In addition, the findings support the notion that a mispricing-based explanation is more plausible in China due to the speculative features of the Chinese markets.
\end{abstract}

Keywords: book to market ratio, stock returns, Chinese capital markets

\section{Introduction}

The book to market effect for stock returns remains inconclusive in the finance literature. Fama and French (1992) argue that book to market ratio has more explanatory power for the cross section of average stock returns than beta does based on the empirically evidence from their study. Similarly, value strategies supporters argue that stock with low price to earnings ratio outperform the market (Basu, 1977; Chan et al. 1991; Fama \& French, 1992; Noda et al. 2016). However, the interpretation of these empirical findings remains controversial. So far we have two competing theories to explain this phenomenon. However, it is fair to say that no single hypothesis has received overwhelming empirical support to reject reasonable alternative explanations.

The primary research question of this study is whether the book to market ratio acts as a proxy for risk or mispricing. In addition, it is motivated by the need to test the robustness of Peterkort and Neilsen (2005) and Dempsey (2010) findings in alternative settings. Chinese markets are chosen for the following reasons. Firstly, Fama and French (1998) find that the value effect is captured by a book to market equity ratio in 12 out of 13 major markets. However, the Chinese markets were not included in their study, because the data sample for their study covers the period from 1974 to 1995 for these 13 markets, while the Shanghai stock exchange was established in 1990, followed by the opening ceremony of Shenzhen Stock Exchange in 1991. Therefore, it is understandable that Chinese markets were ignored in their study. However, in the past two decades, the number of listed company has increased from initially 10 in 1990 to 2,494 by the end of 2012. The total market value of all listed stocks increased from 3 billion RMB in 1990 to 23,035.7 in 2012, which is 7,678 times more than that in 1990. In addition, China has experienced dynamic economic growth since 1987, and has become the second largest economy in the world after US in 2010 (Bloomberg 2010). Therefore, this study contributes to an understanding of the literature addressing the association of book to market ratio and stock returns from the dynamic, yet unsophisticated, Chinese stock markets. Secondly, the unique features of Chinese markets imply that Chinese stocks might behave differently from stocks in other markets. In China, the major shareholders are likely to be institutions and the state rather than individuals, and, the state still controls a significant number of listed companies in China even after three decades of economic form and privatisation (Claessens \& Fan 2002; Li \& Naughon 2007; Gul et al. 2010; Tang et al. 2017). In addition, Chinese public firms are typically highly concentrated, which is normally motivated by the benefits of control due to a weak legal system (Hovey et al. 2003; Holdderness 2003; Li \& Naughton 2007). Furthermore, the existence of non-tradeable state shares reduced market liquidity and has become a major obstacle to market efficiency before 2005 (Allen et al. 2005; Hovey \& Naughton 2007; Fan et al. 2007; Dempsey 2012; Wang \& Chong 2017).

In 2005 , the Chinese authorities introduced a program of gradual floatation of non-tradeable shares for all domestically listed companies. This ongoing reform will have an extensive impact on the investment community and financial system in China in the long run. The overall trading evidence shows that the original non-tradeable 
shareholders gradually reduce their shareholdings but still retain control through the creation of a less concentrated ownership structure. Chinese data for this study, therefore, has considerably divergent characteristic from data obtained from developed markets. The reminder of this paper is organised as follows. Section 2presents the relevant literature. Section 3 discusses the data and methodology employed in this study. Section 4 reports empirical results of this study. Finally, section 5 presents our conclusions.

\section{Literature Review}

Laknoishok et al (1994) state that stocks with high earning to price ratio tend to outperform the market mainly due to systematic mispricing. The mispricing stems from the irrational expectations related to firms' future performance and market valuation formed by naive investors. As a result, out of favor stocks are relatively under-priced, leading to low capital gains. This argument is supported by other studies. For example, Arnott et al (2005) claim that over-priced stocks are normally associated with a low book to market ratio, while the under-priced stocks tend to have high a book to market ratio.

Alternatively, Fama and French (1992 \&1993) argue that value stocks provide returns because they are fundamentally risker, and book to market ratio is a proxy for risk, which is confirmed by their recent studies ( Fama \& French 2015 \& 2016) Stocks with high book to market ratio are associated with higher level of fundamental risk, and, therefore, the high average returns are the compensation for bearing extra risk. Similarly, Chan and Chen (1991) argue that firms with high book to market ratio are more likely to be finically distressed. Vassalou and Xing (2004) report that book to market ratio can be used as an indicator for default risk which is systematically priced and captured by book to market ratio in their study. In addition, Agarwal and Poshakwale (2010) and Chen (2012) support the risk-based explanation for the book-to-market in stock returns. However, Golubov and Konstantinidi (2016) question the risk-based explanations for the value premium in their study. As a result, the question remains whether value strategies provide higher returns because of systemically "mispricing" or "risk-based" perspectives. However, from both the "mispricing" and "risk-based" perspectives, the book to market ratio is treated as the outcome of price adjustments.

Turning to our understanding of Chinese markets, the literature on the book to market effect in Chinese markets remains inconclusive. Surprisingly, literature on Chinese markets mainly focuses on the issues of privatization and firm performance (Hovey et al. 2003; Qi et al. 2000; Wang et al. 2016), IPOs aftermarket performance (Chan et al. 2004; Li \& Naughton, 2007), and price differentials among different classes of shares (Sun \& Tong, $2000,2003)$. Wang (2004) find that firm size, and book-to-market ratio, have a similar impact on stock returns to those in other markets, that is, small stocks outperform large stocks, and value stocks outperform growth stocks. Eun and Huang (2007) confirm that firm size has a significant and negative effect on stock returns. On the other hand, the book-to-market ratio is found to have a significant and positive effect on stock returns, which are consistent with findings of Fama and French (1998) and Rouwenhorst (1999). In addition, they also report that Chinese investors value A shares more if there are offshore counterparts available (such as B H shares) due to A shares' extra liquidity premium. Drew et al. (2003), on the other hand, claim that book to market ratio is negatively related to stock returns. Dempsey (2012) finds that book to market ratio captures 'value-for-money' firms with lower levels of debt. However, his paper does not mention projection function of the book to market ratio in Chinese markets. Moosa and $\mathrm{Li}$ (2011) argue that trading activity in Chinese markets is dominated by individual investors, because shares controlled by the government are not traded. In addition, Chinese individual investor lack investment knowledge and skill in general, resulting in the dominance of "noise traders'. The behaviour of noise traders explains certain market anomalies in China, such as extensive speculation and excess volatility.

\section{Data and Methodology}

Following Peterkort and Nielsen (2005) and Dempsey (2010), we conduct a series of diagnostics tests and try to interpret the relation between stock returns and book to market ratio from risk-based and mispricing-based theories respectively by using Chinese data. Our initial data sample includes all public firms in China from 1999-2011, obtained from the China Stock Market Trading database. To deal with outliners and the (extremely) misreported data, we winsorize all firm level variable at $1 \%$ level in both tails of the distribution. As a result, a total of 18,738 firm year observations survived out filtering criteria to be included in the final sample. Panel A of table 1 reports the distribution of firms and their market value on a yearly basis.

In terms of calculation of variables, we capture market leverage (MLEV) as debt to debt and market value of equity $\mathrm{D} /(\mathrm{D}+\mathrm{ME})$, and book leverage (BLEV) as debt to book value of total asset $\mathrm{D} /(\mathrm{D}+\mathrm{BE})$. Here $\mathrm{D}$ is calculated as book value of total assets minus book value of shareholders' equity. BE is the book value of shareholders' equity and ME is the market value of equity. In addition, we also include variables SIZE and 
PRICE to control problem of bias in measured returns resulting from transaction and liquidity cost (Kross 1985; Bhardwaj \& Brooks 1992). Size is measured as $\ln$ (ME) and PRICE is captured as (1/share price).

Panels B and C of table 1 present the summary statistics and Pearson correlation coefficients for average yearly returns. In this study, we use the stock return in the current year $\left(\right.$ RETURN $\left._{t}\right)$ and stock returns in the following year $\left(\right.$ RETRUN $\left._{t+1}\right)$ respectively to measure the market performance of our sample firms. As observed, Panel C shows that MLEV and BLEV are highly correlated which is consistent with the findings of Peterkort and Nielsen $(72 \%)$ and Dempsey (24\%). Similarly, we also find a strong negative correlation between B/M and SIZE $(-20.3 \%)$ and a strong positive correlation between BLEV and SIZE $(20.27 \%)$, which is consistent with the literature (Dempsey, 2010). Interestingly, we find a strong negative correlation between $\mathrm{B} / \mathrm{M}$ and $\mathrm{RETURN} \mathrm{N}_{\mathrm{t}}$ however, the $\mathrm{B} / \mathrm{M}$ and RETRUN $\mathrm{t}_{\mathrm{t}+1}$ are negatively correlated. One possible explanation for this finding could be that Chinese markets are dominated by individual investors particularly prior to 2005 . These investors mainly focus on short term capital gain instead of long term return and thereby increase the market volatility. (Eun \& Huang 2007; Moosa \& Li 2011).

Table 1. Sample characteristics and summary statistics

\begin{tabular}{|c|c|c|c|c|c|}
\hline \multicolumn{6}{|c|}{ Panel A: Sample Size and Market Value(average), by Year } \\
\hline year & Firm & $\begin{array}{l}\text { Value (RMB } \\
\text { 100Million) }\end{array}$ & year & Firm & mean \\
\hline 1999 & 939 & 2.173056 & 2006 & 1396 & 16.23856 \\
\hline 2000 & 1076 & 2.989507 & 2007 & 1521 & 31.45438 \\
\hline 2001 & 1148 & 3.303249 & 2008 & 1602 & 30.77943 \\
\hline 2002 & 1212 & 3.784521 & 2009 & 1651 & 42.83082 \\
\hline 2003 & 1270 & 4.50685 & 2010 & 2032 & 47.47402 \\
\hline 2004 & 1352 & 4.743902 & 2011 & 2192 & 48.84158 \\
\hline 2005 & 1347 & 5.294986 & & & \\
\hline
\end{tabular}

\begin{tabular}{cccccc}
\hline \multicolumn{2}{l}{ Panel B: Summary Statistics } & & & & \\
\hline Variable & Obs & Mean & Std. Dev. & Min & Max \\
\hline RETURN $_{\mathrm{t}}$ & 16431 & 0.086298 & 0.628097 & -2.2167 & 17.1368 \\
RETURN $_{\mathrm{t}+1}$ & 16479 & 0.081975 & 0.61986 & -1 & 17.1368 \\
B/M & 18738 & 0.362676 & 0.186849 & -0.45994 & 1.179778 \\
Ln(B/M) & 18454 & -1.13886 & 0.622835 & -8.38809 & 0.165326 \\
MLEV & 18738 & 0.247905 & 0.116361 & 0.000217 & 0.71587 \\
BLEV & 18738 & 0.486308 & 0.228648 & 0.001725 & 2.186344 \\
SIZE & 18738 & 21.79604 & 1.185172 & 17.84086 & 30.40361 \\
PRICE & 18713 & 0.149567 & 0.103647 & 0.003571 & 2.715907 \\
\hline
\end{tabular}

\begin{tabular}{|c|c|c|c|c|c|c|c|c|}
\hline \multicolumn{9}{|c|}{ Panel C: Correlation Matrix } \\
\hline & $\mathrm{B} / \mathrm{M}$ & $\operatorname{Ln}(\mathrm{B} / \mathrm{M})$ & MLEV & BLEV & SIZE & PRICE & RETURN $_{\mathrm{t}}$ & RETURN $_{t+1}$ \\
\hline $\mathrm{B} / \mathrm{M}$ & 1 & & & & & & & \\
\hline $\operatorname{Ln}(B / M)$ & 0.8887 & 1 & & & & & & \\
\hline MLEV & -0.084 & -0.043 & 1 & & & & & \\
\hline BLEV & 0.6081 & -0.5836 & 0.7962 & 1 & & & & \\
\hline SIZE & -0.203 & -0.1874 & 0.1302 & 0.2027 & 1 & & & \\
\hline PRICE & 0.2766 & 0.1544 & -0.0529 & -0.1712 & -0.4254 & 1 & & \\
\hline RETURN $_{\mathrm{t}}$ & -0.277 & -0.2566 & -0.1874 & 0.0173 & 0.1372 & -0.2788 & 1 & \\
\hline RETURN $_{t+1}$ & 0.2474 & 0.2102 & 0.151 & -0.0312 & -0.1827 & 0.3216 & -0.2194 & 1 \\
\hline
\end{tabular}




\section{Empirical Findings}

\subsection{Bivariate Sorting}

Following Peterkort and Nielsen (2005) and Dempsey (2010), we employ a bivariate sorting procedure that allows us to examine the relationships among MLEV, B/M, BLEV and two stock returns variables. The bivariate sorting is conducted as follows: (1) for each year in our sample, we sort firms into five MLEV quintile portfolios; (2) we sort each of the MLEV quintile portfolios to create five B/M sub-quintile portfolios, which provides 25 portfolios for each year in the sample; (3) the mean value of B/M, BLEV and average stock return are calculated for each portfolio for each year. This double sort procedure is designed to reveal patterns of key ratios related to the primary sort variable, in this case, MLEV. The results are presented in Panels A, B, C and D of Table 2.

Table 2. Average $\mathrm{B} / \mathrm{M}$ ratio, $\mathrm{BLEV}$, and stock returns for portfolios formed on $\mathrm{MLEV}$ and $\mathrm{B} / \mathrm{M}$ ratio

\begin{tabular}{|c|c|c|c|c|c|}
\hline & \multicolumn{5}{|l|}{ MLEV } \\
\hline & low & 2 & 3 & 4 & high \\
\hline Panel A & \multicolumn{5}{|c|}{ Average $\mathrm{B} / \mathrm{M}$} \\
\hline B/M low & 0.1211 & 0.1519 & 0.1625 & 0.1565 & 0.0211 \\
\hline $\mathrm{B} / \mathrm{M} 2$ & 0.2401 & 0.2719 & 0.2897 & 0.2876 & 0.2112 \\
\hline $\mathrm{B} / \mathrm{M} 3$ & 0.3579 & 0.3722 & 0.3856 & 0.3704 & 0.2898 \\
\hline $\mathrm{B} / \mathrm{M} 4$ & 0.5033 & 0.4867 & 0.4875 & 0.4524 & 0.3588 \\
\hline $\mathrm{B} / \mathrm{M}$ high & 0.7010 & 0.6738 & 0.6517 & 0.5809 & 0.4820 \\
\hline Panel B & \multicolumn{5}{|c|}{ Average BLEV } \\
\hline $\mathrm{B} / \mathrm{M}$ low & 0.406 & 0.6011 & 0.6898 & 0.7716 & 1 \\
\hline $\mathrm{B} / \mathrm{M} 2$ & 0.2801 & 0.4413 & 0.5326 & 0.6235 & 0.7703 \\
\hline $\mathrm{B} / \mathrm{M} 3$ & 0.2112 & 0.3674 & 0.4618 & 0.5603 & 0.6978 \\
\hline $\mathrm{B} / \mathrm{M} 4$ & 0.1535 & 0.3095 & 0.407 & 0.5103 & 0.6463 \\
\hline $\mathrm{B} / \mathrm{M}$ high & 0.115 & 0.2441 & 0.3368 & 0.4454 & 0.5729 \\
\hline Panel C & \multicolumn{5}{|c|}{ Average stock returns in current year: RETURN $_{t}$} \\
\hline $\mathrm{B} / \mathrm{M}$ low & 0.6976 & 0.4374 & 0.3353 & 0.2005 & 0.0229 \\
\hline $\mathrm{B} / \mathrm{M} 2$ & 0.3641 & 0.2487 & 0.131 & 0.0411 & 0.0629 \\
\hline $\mathrm{B} / \mathrm{M} 3$ & 0.1436 & 0.0806 & 0.0045 & -0.0425 & 0.0036 \\
\hline $\mathrm{B} / \mathrm{M} 4$ & -0.0825 & -0.0525 & -0.0715 & -0.0421 & -0.0002 \\
\hline $\mathrm{B} / \mathrm{M}$ high & -0.2085 & -0.1278 & -0.1022 & -0.0878 & -0.0811 \\
\hline Panel D & \multicolumn{5}{|c|}{ Average stock returns in following year: RETURN $_{t+1}$} \\
\hline $\mathrm{B} / \mathrm{M}$ low & -0.3089 & -0.2636 & -0.1564 & -0.0865 & 0.1093 \\
\hline B/M 2 & -0.1557 & -0.1169 & 0.0253 & 0.0768 & 0.1646 \\
\hline B/M 3 & -0.0805 & 0.0428 & 0.1493 & 0.1955 & 0.1944 \\
\hline $\mathrm{B} / \mathrm{M} 4$ & 0.0228 & 0.1796 & 0.2215 & 0.2497 & 0.1959 \\
\hline $\mathrm{B} / \mathrm{M}$ high & 0.1981 & 0.3316 & 0.2967 & 0.2927 & 0.2672 \\
\hline
\end{tabular}


The first thing to note in Panel A of Table 2 is that $\mathrm{B} / \mathrm{M}$ increases as MLEV decreases, while each quintile of MLEV allows for a quite a wide range of B/M if we read down in each column of Panel A. Therefore, it is safe to conclude that $\mathrm{B} / \mathrm{M}$ cannot be treated as the outcome of market leverage. Similarly, the trend of stocks on $\mathrm{B} / \mathrm{M}$ (Panel A) is inversely correlated with the ranking on BLEV in Panel B if MLEV is controlled. In addition, information from Panel C shows that holding MLEV consistent, average stock returns in current year tend to decrease with increasing $\mathrm{B} / \mathrm{M}$, which is not consistent with the findings of Peterkort and Nielsen (2004) and Dempsey (2010). However, the results are consistent with the findings of Fama and French (1992) that B/M appears to have additional explanatory power for stock returns when compared to market leverage alone. We also summarise the stock returns in following years in panel D. It is interesting to notice that stock returns in following years tend to increase with increasing $\mathrm{B} / \mathrm{M}$ and decreasing MLEV, which is the opposite pattern to stock returns for the current year. However, after combining findings from all four Panels of Table 2, we conclude that the returns of Chinese stocks can be either explained by mispricing (measured by B/M), or by the differences in asset risk (captured by MLEV). Therefore, the "mispricing" versus "asset risk" explanation remains unsolved at this stage.

\subsection{Quintile Portfolios Formed on B/M}

We next investigate the effect of $\mathrm{B} / \mathrm{M}$ on the sample data by using a univariate sorting analysis. First, annul quintile portfolios are created by sorting the $\mathrm{B} / \mathrm{M}$ ratio of sample firms. Second, the annual average stock returns, MLEV, BLEV, PRICE, and SIZE are calculated for each portfolio. The data analysis process will help us to have a deeper understanding of the relationship between these variables and $\mathrm{B} / \mathrm{M}$ ratio.

Table 3

\begin{tabular}{lrrrrr}
\hline B/M (Panel A) & \multicolumn{1}{c}{ Low } & 2 & 3 & 4 & High \\
\hline B/M & 0.118 & 0.2589 & 0.3503 & 0.4529 & 0.6333 \\
\hline RETURN $_{\mathrm{t}}$ & 0.3439 & 0.1619 & 0.0398 & -0.0528 & -0.1195 \\
\hline RETURN $_{\mathrm{t}+1}$ & -0.1307 & -0.0105 & 0.1069 & 0.1876 & 0.2598 \\
\hline MLEV & 0.2583 & 0.2621 & 0.2682 & 0.2495 & 0.2014 \\
\hline BLEV & 0.6968 & 0.5484 & 0.4918 & 0.4112 & 0.2833 \\
\hline Price & 0.1385 & 0.1271 & 0.1398 & 0.1553 & 0.1871 \\
\hline Size & 22.164 & 21.965 & 21.745 & 21.588 & 21.518 \\
\hline
\end{tabular}

\begin{tabular}{lrrrrr}
\hline B/M with low MLEV and LEV (Panel B) & \multicolumn{3}{l}{} \\
\hline & \multicolumn{1}{l}{ Low } & 2 & 3 & 4 & High \\
\hline B/M & 0.2317 & 0.4806 & 0.5863 & 0.6776 & 0.8254 \\
\hline RETURN $_{\mathrm{t}}$ & 0.4018 & -0.2431 & -0.346 & -0.2736 & -0.2487 \\
\hline RETURN $_{\mathrm{t}+1}$ & -0.1242 & 0.1604 & -0.1372 & 0.1328 & 0.1976 \\
\hline MLEV & 0.0065 & 0.0152 & 0.0204 & 0.0205 & 0.0292 \\
\hline BLEV & 0.0282 & 0.031 & 0.0343 & 0.03 & 0.0352 \\
\hline Price & 0.1873 & 0.1432 & 0.1263 & 0.158 & 0.2221 \\
\hline Size & 21.389 & 21.325 & 21.555 & 21.048 & 21.23 \\
\hline
\end{tabular}

Table 3 Panel A presents the results for our base total sample. Again the results show that average stock returns in the current year decrease as B/M increases, which is inconsistent with the findings of Fama and French (1992) 
and Peterkort and Nielsen (2005). Again, we also try to capture the projection power of B/M and LEV on future stock returns in Chinese markets. As observed, the following year's stock returns and $B / M$ are positively correlated. In addition, we find that the average stock returns in following year and B/M increase as BLEV decreases, showing an opposite correlation direction with B/M and BLEV of the current year. Overall, a strong link is observed between these variables and stock returns.

However, what remains unclear is whether $\mathrm{B} / \mathrm{M}$ is capturing market information effects other than leverage. The literature shows that $\mathrm{B} / \mathrm{M}$ can be viewed as a combined measure of asset risk and financial risk as $\mathrm{B} / \mathrm{M}$ can be measured as market leverage divided by book leverage (Peterkort \& Nielsen 2005). The book leverage acts as a measure of leverage policy, and firms with risky assets tend to lower their leverage ratio (Fama \& French 1998), thus assets risk increases as book leverage decreases. Market leverage, on the other hand, can be used as a proxy of financial risk, as the change of market leverage mainly depends on the fluctuations in the market value of equity.

Based on these arguments, we can reach two competing explanations First, it is fair to say that $\mathrm{B} / \mathrm{M}$ is acting as a proxy for leverage as B/M and BLEV are highly related. In addition, changes in firm's market value can lead to the changes in MLEV, which upholds an asset risk explanation. On the other hand, an equally valid alternative is that $\mathrm{B} / \mathrm{M}$ can be treated as a risk proxy for leverage as a risk factor as stocks are mispriced. The results reveal that $\mathrm{B} / \mathrm{M}$ and $\mathrm{BLEV}$ are highly correlated $(60.81 \%)$, so that leverage acts as a proxy for $\mathrm{B} / \mathrm{M}$ as mispricing. It is worth noting that a positive relation is expected between average stock returns and the $\mathrm{B} / \mathrm{M}$ ratio consistent with both "asset risk" and "mispricing" explanations (Fama \& French 1992; Opler \& Titman 1994; Cassalou \& Xing 2004).

The use of all equity firms allow us to distinguish between these two competing explanations. The logic is straightforward. If the $\mathrm{B} / \mathrm{M}$ effect is the outcome of financial leverage, then it should not be revealed for all equity firms. Alternatively, the $\mathrm{B} / \mathrm{M}$ effect should continue to be observed for all equity firms if the mispricing explanation is correct. Following Peterkort and Nielsen (2005) and Dempsey (2010), we define all equity firms as firms with BLEV and MLEV less than 0.05 . Panel B of table 3 presents the results for the all equity sample and shows that the average stock returns in the current year are negatively correlated with $B / M$, and the average stock returns in following year are positively correlated with $\mathrm{B} / \mathrm{M}$. Hence, we conclude that the mispricing explanation can be accepted. The explanation links with Moosa and Li (2011) who argue that trading activity in Chinese markets is dominated by individual investors, because shares controlled by the government are rarely traded, especially before 2005. In addition, Chinese individual investor lack investment knowledge and skill in general, resulting in the dominance of "noise traders'. Furthermore, Chinese investors, generally speaking, are short term focused. The behaviour of short term focused noise trader explains anomalies in China, such as extensive speculation and excess volatility. Thus, the relationship between $\mathrm{B} / \mathrm{M}$ and stock returns can change dramatically in a short period of time (one year), which is less likely the case in developed markets. De Bondt and Thaler (1985\&1987) also argue that extreme losers might outperform the market over the subsequent years. In this study, we did not perform analyses on firms with negative book equity due to the limited observations.

\subsection{Fama-MacBeth and Pooled Time-Series Cross-Sectional Regressions}

We used both the Fama-Macbeth (1973) regressions and pooled time series cross-sectional regressions to further examine the relationship among B/M, MLEV and stock returns. Annual stock returns in the current year and following year are regressed on B/M, LEV and MLEV. Following Peterkort and Nielsen (2005) and Dempsey (2010), we also include SIZE and PRICE as control variables for transaction and liquidity costs. The Fama-MacBeth (1973) results are presented in Table 4, and the pooled regressions results are shown in Table 5. Furthermore, panel A and B of Table 4 and 5 present the results from Fama-MacBeth (1973) and pooled regressions for the entire base sample. Panel C and D of Table 4 and 5 present the results from Fama-MacBeth (1973) and pooled regressions for the all equity sample only.

For the whole sample, the results from Panel A Table 4 and 5 shows that in contrast with the literature, the annual average stock returns in the current year are negatively and significantly related to B/M. These results are consistent across all regressions. However, findings from Panel B Table 4 and 5 show that the annual average stock returns in the following year are positively and significantly related to $\mathrm{B} / \mathrm{M}$, which is consistent with the findings of Fama-Macbeth (1973) and Peterkort and Nielsen (2005) and Dempsey (2010), and further confirm the projection power of $\mathrm{B} / \mathrm{M}$. The findings are interesting, but consistent with the notion that Chinese markets are relatively speculative and volatile, compared to other mature markets. Empirical evidence shows that Chinese markets are dominated by individual investors, and they account for at least $90 \%$ of stocks turnovers (Eun and Huang, 2007). Mok and Hui (1998) conclude that Chinese individual investors in general are short of 
investment knowledge, and mainly look for short-term capital speculation, rather than long-term investment returns, which is confirmed by Hovey et al. (2003), and Moosa and Li (2011). In addition, Eun and Huang (2007) find that the average annual stock turnover ratio was nearly $483 \%$ in their study, far exceeding the turnover ratios observed in developed markets. Similar results are found in other studies (Xu and Wang, 1999; Chen et al, 2010). Therefore, it is not surprising to see that Chinese individual investors seldom pay attention to the fundamental characteristics of companies closely, rather than pursuing the short term capital gain from selling outperformers. As a result, the current market outperformers are more likely to underperform in the next period.

From panel A and B Table 4, we also observe that the average coefficient estimates of MLEV does not have significant explanatory power on stock returns in either current year or following year. However, the results of pooled regression in Table 5 shows that MLEV is significantly negatively related to the current year stock returns, and significantly positively related to returns in following year. Therefore, at least we can say that these two variables (B/M and MLEV) are acting in the same directions on stock returns.

When we place B/M and MLEV in the same regression, the explanatory power of B/M and MLEV remains approximately unchanged in terms of the $t$ test. Similar patterns can be found if we use stock returns in the following year as the dependent variable. Overall, it is safe to conclude that $\mathrm{B} / \mathrm{M}$ has significant influence on the stock returns in China. MLEV on the other hand, does not show a consistent significant impact on stock return across all regressions. Therefore, the mis-pricing explanation appears more plausible for Chinese stocks, which is consistent with investors' behaviour.

Table 4. Average Coefficient Estimate from Yearly Fama-MacBeth (1973) Regressions of Yearly Stock Returns on $\operatorname{Ln}(\mathrm{B} / \mathrm{M})$, MLEV, SIZE and PRICE

\begin{tabular}{|c|c|c|c|c|c|c|c|c|c|c|c|}
\hline \multicolumn{2}{|c|}{ Current Year Return } & \multicolumn{4}{|c|}{ Panel A: Base Sample } & \multicolumn{2}{|c|}{ Future Return } & \multicolumn{4}{|c|}{ Panel B: Base Sample } \\
\hline Intercept & $\operatorname{Ln}(b / M)$ & MLEV & SIZE & PRICE & Ave Adj $R^{2}$ & Intercept & $\operatorname{Ln}(b / M)$ & MLEV & SIZE & PRICE & Ave Adj $R^{2}$ \\
\hline $\begin{array}{c}-0.0467 \\
(-0.5859) \\
\end{array}$ & $\begin{array}{c}-0.1094 \\
(-2.9862) \\
\end{array}$ & & & & 0.0218 & $\begin{array}{l}0.1548 \\
(1.176) \\
\end{array}$ & \begin{tabular}{|l|}
0.0572 \\
$(3.311)$ \\
\end{tabular} & & & & 0.0240 \\
\hline $\begin{array}{c}0.1519 \\
(0.7685) \\
\end{array}$ & & $\begin{array}{c}-0.2947 \\
(-0.8668) \\
\end{array}$ & & & 0.0412 & $\begin{array}{c}0.1571 \\
(0.8553) \\
\end{array}$ & & $\begin{array}{c}-0.1533 \\
(-0.6618) \\
\end{array}$ & & & 0.0413 \\
\hline $\begin{array}{c}-0.1810 \\
(-0.4267) \\
\end{array}$ & $\begin{array}{l}-0.1003 \\
(-2.625) \\
\end{array}$ & & $\begin{array}{r}0.0126 \\
(0.7952) \\
\end{array}$ & $\begin{array}{c}-0.9315 \\
(-3.5922) \\
\end{array}$ & 0.1091 & $\begin{array}{c}0.0573 \\
(0.1405) \\
\end{array}$ & $\begin{array}{l}0.0442 \\
(3.201)\end{array}$ & & $\begin{array}{c}-0.0035 \\
(-0.2012) \\
\end{array}$ & $\begin{array}{c}1.0510 \\
(3.7731) \\
\end{array}$ & 0.0404 \\
\hline $\begin{array}{c}0.0168 \\
-0.1165 \\
\end{array}$ & $\begin{array}{r}-0.0987 \\
(-2.333) \\
\end{array}$ & $\begin{array}{c}-0.2974 \\
(-0.8369) \\
\end{array}$ & & & 0.0720 & $\begin{array}{l}0.1846 \\
(1.022) \\
\end{array}$ & $\begin{array}{l}0.0422 \\
(1.807) \\
\end{array}$ & $\begin{array}{c}-0.0736 \\
(-0.2814) \\
\end{array}$ & & & 0.0609 \\
\hline $\begin{array}{c}-0.2803 \\
(-0.9215) \\
\end{array}$ & $\begin{array}{c}-0.1046 \\
(-2.5870) \\
\end{array}$ & $\begin{array}{c}-0.4970 \\
(-1.3687) \\
\end{array}$ & $\begin{array}{r}0.0216 \\
(2.2858) \\
\end{array}$ & $\begin{array}{l}-0.9432 \\
(-3.456) \\
\end{array}$ & 0.1506 & $\begin{array}{c}0.2269 \\
(0.6197) \\
\end{array}$ & $\begin{array}{c}0.0370 \\
(1.7672) \\
\end{array}$ & $\begin{array}{c}0.0701 \\
(0.3310) \\
\end{array}$ & $\begin{array}{c}-0.0111 \\
(-0.7353) \\
\end{array}$ & $\begin{array}{l}1.0364 \\
(3.912) \\
\end{array}$ & 0.1360 \\
\hline Current Y & ar Return & Panel C (BL & EV\&MLEV & $0.05)$ & & uture Retu & rnPanel D & (BLEV\&ML & $E V<0.05)$ & & \\
\hline Intercept & $\operatorname{Ln}(b / M)$ & MLEV & SIZE & PRICE & Ave Adj $R^{2}$ & Intercept & $\operatorname{Ln}(\mathrm{b} / \mathrm{M})$ & MLEV & SIZE & PRICE & Ave Adj R \\
\hline $\begin{array}{r}-0.3614 \\
(-2.675) \\
\end{array}$ & $\begin{array}{r}-0.3886 \\
(-1.391) \\
\end{array}$ & & & & 0.1513 & $\begin{array}{c}0.0306 \\
(0.2756) \\
\end{array}$ & $\begin{array}{c}-0.7060 \\
(-0.9228) \\
\end{array}$ & & & & 0.0152 \\
\hline $\begin{array}{c}0.2742 \\
(0.8463) \\
\end{array}$ & & $\begin{array}{c}-12.2160 \\
(-1.029) \\
\end{array}$ & & & -0.0280 & $\begin{array}{l}0.6703 \\
(1.077) \\
\end{array}$ & & $\begin{array}{r}-16.8549 \\
(-1.139) \\
\end{array}$ & & & 0.3140 \\
\hline $\begin{array}{l}-30.3497 \\
(-0.9926) \\
\end{array}$ & $\begin{array}{r}-2.9460 \\
(-1.197) \\
\end{array}$ & & $\begin{array}{r}1.2866 \\
(0.9659) \\
\end{array}$ & $\begin{array}{c}0.9501 \\
(0.9401) \\
\end{array}$ & 0.1603 & $\begin{array}{c}-2.01 \\
(-0.5766) \\
\end{array}$ & $\begin{array}{c}-1.27835 \\
(-1.165) \\
\end{array}$ & & $\begin{array}{r}0.07488 \\
(0.4736) \\
\end{array}$ & $\begin{array}{l}1.3292 \\
(1.513) \\
\end{array}$ & -0.0212 \\
\hline $\begin{array}{l}-0.9701 \\
(-1.779) \\
\end{array}$ & $\begin{array}{r}-0.9732 \\
(-1.523) \\
\end{array}$ & $\begin{array}{r}14.0126 \\
(0.8257) \\
\end{array}$ & & & 0.0780 & $\begin{array}{l}-14.7435 \\
(-0.9903) \\
\end{array}$ & $\begin{array}{r}-17.783 \\
(-0.9948) \\
\end{array}$ & $\begin{array}{r}314.898 \\
(0.9908) \\
\end{array}$ & & & 0.0942 \\
\hline $\begin{array}{r}-30.6300 \\
(-1.003) \\
\end{array}$ & $\begin{array}{c}-2.7208 \\
(-1.1816) \\
\end{array}$ & $\begin{array}{r}-5.1903 \\
(-1.0094) \\
\end{array}$ & $\begin{array}{l}1.3076 \\
(0.983) \\
\end{array}$ & $\begin{array}{c}0.9053 \\
(0.8905) \\
\end{array}$ & 0.0984 & $\begin{array}{l}-10.2325 \\
(-1.1035) \\
\end{array}$ & $\begin{array}{c}-5.90784 \\
(-1.221) \\
\end{array}$ & $\begin{array}{c}195.3236 \\
(1.012) \\
\end{array}$ & $\begin{array}{c}-0.0735 \\
(-0.3496) \\
\end{array}$ & $\begin{array}{r}28.59268 \\
(1.0204) \\
\end{array}$ & -0.0720 \\
\hline
\end{tabular}

The results for the all equity sample of the Fama-Macbeth (1973) and pooled time-series cross-sectional regression analysis for all equity samples are presented in panel $\mathrm{C}$ and $\mathrm{D}$ of Table 4 and 5 respectively. Generally speaking, we find that both B/M and MLEV have lost their explanatory power for the stock returns, in both the current year and following year, except B/M in Panel C Table 5. The results from Panel $\mathrm{C}$ table 5 appear to contradict the leverage explanation prediction of no book to market effect. Therefore, it is difficult for us to reject the notion that both mis-pricing and risk explanations do not work for all equity Chinese firms. In addition, we believe that the decreased explanatory power of B/M and MLEV is mainly attributed to the small sample of all equity Chinese firms. It is difficult to find all equity firms in our sample. We have defined all equity firms as 
firms with MLEV and BLEV values less than 0.05. However, we only have 102 firm year observations. When the SIZE and PRICE are included as control variables in the regression, we do not find consistent significant impact on the dependent variables. In addition, none of these variables establish significant impact on the dependent variables despite the fact that several combinations were considered.

Table 5. Coefficient Estimate from Pooled Regressions of average yearly returns on $\operatorname{Ln}(\mathrm{B} / \mathrm{M})$, MLEV, SIZE and PRICE

\begin{tabular}{|c|c|c|c|c|c|c|c|c|c|c|c|}
\hline \multicolumn{4}{|c|}{ Current Year Return Panel A: Base Sample } & \multirow{2}{*}{\begin{tabular}{|l} 
PRICE \\
\end{tabular}} & \multirow[b]{2}{*}{ Ave Adj R ${ }^{2}$} & \multicolumn{4}{|c|}{ Future Year Return Panel B: Base Sample } & \multirow{2}{*}{\begin{tabular}{|l|} 
PRICE \\
\end{tabular}} & \multirow[b]{2}{*}{ Ave Adj R } \\
\hline Intercept & $\operatorname{Ln}(\mathrm{b} / \mathrm{M})$ & MLEV & SIZE & & & Intercept & $\operatorname{Ln}(\mathrm{b} / \mathrm{M})$ & MLEV & SIZE & & \\
\hline$-0.189 * * *$ & $-0.236 * * *$ & & & & 0.057 & $0.302 * * *$ & $0.192^{* * *}$ & & & & 0.037 \\
\hline$(-18.74)$ & $(-31.22)$ & & & & & $(30.06)$ & $(24.82)$ & & & & \\
\hline $0.271^{* * *}$ & & $-0.722 * * *$ & & & 0.018 & $-0.125 * * *$ & & $0.826 * * *$ & & & 0.023 \\
\hline$(22.94)$ & & $(-17.15)$ & & & & $(-10.86)$ & & $(19.79)$ & & & \\
\hline $0.432 * * *$ & $-0.209 * * *$ & & $-0.0159 * * *$ & $-1.617^{* * *}$ & 0.118 & $0.380 * * *$ & $0.140 * * *$ & & $-0.0192 * *$ & $1.952 * * *$ & 0.132 \\
\hline$(4.49)$ & $(-28.03)$ & & $(-3.70)$ & $(-32.37)$ & & $(3.94)$ & $(18.65)$ & & $(-4.44)$ & $(37.44)$ & \\
\hline 0.000358 & $-0.245^{* * *}$ & $-0.792^{* * *}$ & & & 0.077 & $0.0826 * * *$ & $0.209 * * *$ & $0.962^{* * *}$ & & & 0.067 \\
\hline$(0.03)$ & $(-32.76)$ & $(-18.96)$ & & & & $(6.02)$ & $(27.34)$ & $(23.02)$ & & & \\
\hline $0.340 * * *$ & $-0.214^{* * *}$ & $-0.882 * * *$ & -0.00169 & $-1.621 * * *$ & 0.143 & $0.540 * * *$ & $0.154 * * *$ & $1.035^{* * *}$ & $-0.0372 * *$ & $1.883^{* * *}$ & 0.167 \\
\hline$(3.58)$ & $(-29.18)$ & $(-21.61)$ & $(-0.39)$ & $(-32.92)$ & & $(5.72)$ & $(20.77)$ & $(25.85)$ & $(-8.67)$ & $(36.80)$ & \\
\hline \multicolumn{5}{|c|}{ Current Year Return Panel C (MLEV \&BLEV<0.05) } & & \multicolumn{5}{|c|}{ Future Year Return Panel D(MLEV\&BLEV<0.05) } & \\
\hline Intercept & $\operatorname{Ln}(\mathrm{b} / \mathrm{M})$ & MLEV & SIZE & PRICE & Ave Adj $R^{2}$ & Intercept & $\operatorname{Ln}(\mathrm{b} / \mathrm{M})$ & MLEV & SIZE & PRICE & Ave Adj $R^{2}$ \\
\hline$-0.383 * * *$ & $-0.378 * * *$ & & & & 0.120 & 0.147 & 0.165 & & & & -0.001 \\
\hline$(-3.51)$ & $(-3.84)$ & & & & & $(0.91)$ & $(0.93)$ & & & & \\
\hline 0.192 & & -15.23* & & & 0.042 & -0.129 & & 8.941 & & & -0.000 \\
\hline$(1.40)$ & & $(-2.33)$ & & & & $(-0.71)$ & & $(0.99)$ & & & \\
\hline-1.184 & $-0.368 * * *$ & & 0.0474 & -0.931 & 0.136 & 2.581 & -0.0352 & & -0.145 & $3.040 * * *$ & 0.164 \\
\hline$(-0.56)$ & $(-3.74)$ & & $(0.49)$ & $(-1.48)$ & & $(1.05)$ & $(-0.21)$ & & $(-1.27)$ & $(3.99)$ & \\
\hline-0.419 & $-0.393^{* *}$ & 1.382 & & & 0.111 & -0.0132 & 0.0863 & 5.933 & & & -0.008 \\
\hline$(-1.71)$ & $(-2.96)$ & $(0.16)$ & & & & $(-0.04)$ & $(0.36)$ & $(0.48)$ & & & \\
\hline-1.171 & $-0.384^{* *}$ & 1.539 & 0.0450 & -0.943 & 0.128 & 2.828 & -0.139 & 7.623 & -0.166 & $2.969 * * *$ & 0.159 \\
\hline$(-0.55)$ & $(-2.88)$ & $(0.18)$ & $(0.46)$ & $(-1.48)$ & & $(1.13)$ & $(-0.60)$ & $(0.65)$ & $(-1.40)$ & $(3.84)$ & \\
\hline
\end{tabular}

\section{Conclusion}

This study aims to examine the relationship between book to market ratio and stock returns in Chinese markets. We employ a set of leverage-based diagnostic test to investigate the question of whether the book to market ratio can be used as "risk-based" or "mispricing-based" proxy to explain stock returns in China. The two competing explanations have proved difficult to distinguish in the literature.

Empirical findings show that a strong negative relationship is found between book to market ratio and stock returns in current year, while a strong positive relationship is detected between book to market ratio and stock returns in following year, implying the strong prediction capability of book to market ratio in the speculative Chinese markets. The empirical findings of this study tend to contradict the evidence observed from other markets (Dempsey 2010; Chen 2012), which in turn enrich our knowledge about the unique features of Chinese markets. Second, regression results reveal that compared with book to market ratio, the market leverage ratio does not establish a consistently significant explanatory power for stock returns. Therefore, we assume that a mispricing-based explanation is appropriate in the Chinese markets. To further investigate the difference between "the risk-based" and "mispricing-based" explanations, a subsample of all-equity firms was created, and the results are consistent with prediction of the mispricing explanation, while contradicting those of the leverage explanation. The extensive speculation and excess volatility observed in Chinese markets can be used to support our findings. Finally, although this study yielded several new findings, we acknowledge that a limitation is that the data analysis covered the period from 1999-2012. Since that time, China has undergone dramatic economic change which provides the direction for future research. 


\section{References}

Agarwal, V., \& Poshakwale, S. (2010). Size and book-to-market anomalies and omitted leverage risk. European Journal of Finance, 16(3), 263-279. https://doi.org/10.1080/13518470903314402

Allen, F., Qian, J., \& Qian, M. (2005). Law, finance, and economic growth in China. Journal of Financial Economics, 77, 57-116. https://doi.org/10.1016/j.jfineco.2004.06.010

Arnott, R., Hsu, J., \& Moore, P. (2005). Fundamental indexation. Financial Analysts Journals, 61, 83-99. https://doi.org/10.2469/faj.v61.n2.2718

Basu, S. (1977). Investment performance of common stocks in relation to their price earnings ratios: a test of the $\begin{array}{llll}\text { efficient market hypothesis. Journal of } & \text { Finance, 32, 663-682. }\end{array}$ https://doi.org/10.1111/j.1540-6261.1977.tb01979.x

Chan, K., Wang, J., \& Wei, K.C.J. (2004). Underpricing and long term performance of IPOs in China. Journal of Corporate Finance, 10, 409-430. https://doi.org/10.1016/S0929-1199(03)00023-3

Chan, K.C., \& Chen, N. (1991). Structural and Return Characteristics of Small and Large Firms. Journal of Finance, 46, 1467-1484. https://doi.org/10.1111/j.1540-6261.1991.tb04626.x

Chan, L., Hamao, Y., \& Lakonishok, J. (1991). Fundamental and stock returns in Japan. Journal of Finance, 46, 1739-1764. https://doi.org/10.1111/j.1540-6261.1991.tb04642.x

Chen, J.W. (2012). Risk-based explanation for the book-to-market effect. Accounting \& Finance, 52, 137-154. https://doi.org/10.1111/j.1467-629X.2011.00442.x

Chen, X.J., Kim, K.A., Yao, T., \& Yu, T. (2010). On the predictability of Chinese stock returns. Pacific-Basin Finance Journal, 18, 403-425. https://doi.org/10.1016/j.pacfin.2010.04.003

Claessens, S., \& Fan, J.P.H. (2002). Corporate governance in Asia: A survey. International Review of Finance, 3(2), 71-103. https://doi.org/10.1111/1468-2443.00034

De Bondt, W., \& Thaler, R. (1985). Does the stock market overact?. Journal of Finance, 40, 793-805. https://doi.org/10.1111/j.1540-6261.1985.tb05004.x

De Bondt, W., \& Thaler, R. (1987). Further evidence on investor overreaction and stock market seasonality. Journal of Finance, 42, 557-581. https://doi.org/10.1111/j.1540-6261.1987.tb04569.x

Dempsey, M. (2010). The book to market equity ratio as a proxy for risk: evidence from Australian markets. Australian Journal of Management, 35(1), 7-21. https://doi.org/10.1177/0312896209351451

Dempsey, M. (2012). Are firm size and book-to-market priced risk factors? Chinese evidence. Retrieved 30 Jan. 2016, from https://ssrn.com/abstract $=1970098$

Drew, M.E., Naughton, T., \& Veeraraghavan, M. (2003). Firm size, book-to-market equity and security returns: evidence from the Shanghai stock exchange. Australia Journal of Management, 28(2), 119-139.

Eun, C.S., \& Huang, W. (2007). Asset pricing in China's domestic stock markets: Is there a logic? Pacific-Basin Finance Journal, 15(5), 452-480. https://doi.org/10.1016/j.pacfin.2006.11.002

Fama, E., \& French, K. (1992). The cross-section of expected stock returns. Journal of Finance, 46, 427-466. https://doi.org/10.1111/j.1540-6261.1992.tb04398.x

Fama, E., \& French, K. (1993). Common risk factors in the returns on stocks and bonds. Journal of Financial Economics, 33, 3-56. https://doi.org/10.1016/0304-405X(93)90023-5

Fama, E., \& French, K. (1998). Taxes, financing decisions, and firm value. Journal of Finance, 53, 819-843. https://doi.org/10.1111/0022-1082.00036

Fama, E., \& French, K. (2015). A five-factor asset pricing model. Journal of Financial Economics, 116, 1-22. https://doi.org/10.1016/j.jfineco.2014.10.010

Fama, E., \& French, K. (2016). Dissecting anomalies with a five-factor model. Review of Financial Studies, 29, 69-103. https://doi.org/10.1093/rfs/hhv043

Fama, E., \& MacBeth, J.D. (1973). Risk, return and equilibrium: empirical tests. Journal of Political Economy, 81, 607-636. https://doi.org/10.1086/260061

Fan, J., Wong, T.J., \& Zhang, T. (2007). Politically connected CEOs, corporate governance, and post-IPO performance of China's newly partially privatized firms. Journal of Financial Economics, 84, 330-357. https://doi.org/10.1016/j.jfineco.2006.03.008 
Golubov, A., \& Konstantinidi, T. (2016). Where Is the risk in value? evidence from a market-to-book decomposition. https://doi.org/10.2139/ssrn.2702822

Holderness, C.G. (2003). A survey of blockholders and corporate control. Economic Policy Review, 9(1), 52-64.

Hovey M., Li, L., \& Naughton, T. (2003). The relationship between valuation and ownership of listed firms in China. Corporate Governance: An International Review, 11(2), 112-122. https://doi.org/10.1111/1467-8683.00012

Hovey, M., \& Naughton, T. (2007). A survey of enterprise reforms in China: The way forward. Economic Systems, 31(2), 138-156. https://doi.org/10.1016/j.ecosys.2006.09.001

Li, L., \& Naughton, T. (2007). Going public with good governance: evidence from China. Corporate Governance: An International Review, 15(6), 1190-1202. https://doi.org/10.1111/j.1467-8683.2007.00640.x

Moosa, I., \& Li, L. (2011). Technical and fundamental trading in the Chinese stock market: evidence based on time series and panel data. Emerging Markets Finance and Trade, 47(1), 23-31. https://doi.org/10.2753/REE1540-496X4701S103

Noda, R., Martelanc, R., \& Kayo, E. (2016). The earnings/price risk factor in capital asset pricing models. Revista Contabilidade \& Finanças, 27(70), 67-79. https://doi.org/10.1590/1808-057x201412060

Opler, T.C., \& Titman, S. (1994). Financial distress and corporate performance. Journal of Finance, 49, 1015-1040. https://doi.org/10.1111/j.1540-6261.1994.tb00086.x

Peterkort, R.F., \& Nielson, J.F. (2005). Is the book to market ratio a measure of risk?. Journal of Financial Research, 28, 487-502. https://doi.org/10.1111/j.1475-6803.2005.00135.x

Qi, D.Q., Wu, W., \& Zhang, H. (2000). Shareholding structure and corporate performance of partially privatized firms: evidence from listed Chinese companies. Pacific-Basin Finance Journal, 8, 587-610. https://doi.org/10.1016/S0927-538X(00)00013-5

Rouwenhorst, K.G. (1999). Local return factors and turnover in emerging stock markets. Journal of Finance, 54, 1439-1464. https://doi.org/10.1111/0022-1082.00151

Sun, Q., \& Tong, W.H.S. (2003). China share issue privatization: the extent of its success. Journal of Financial Economics, 70, 183-222. https://doi.org/10.1016/S0304-405X(03)00145-4

Tang, F., Ruan, L., \& Yang, L. (2017). Does regulator designation of auditors improve independence? Managerial Auditing Journal, 32(1), 2-18. https://doi.org/10.1108/MAJ-03-2016-1334

Vassalou, M., \& Xing, Y. (2004). Default risk in equity returns. Journal of Finance, 59, 831-868. https://doi.org/10.1111/j.1540-6261.2004.00650.x

Wang, C.Y. (2004). Relative strength strategies in China's stock market: 1994-2000. Pacific-Basin Finance Journal, 12(2), 159-177. https://doi.org/10.1016/S0927-538X(03)00043-X

Wang, D., \& Chong, T. (2017). Political turnover and the stock performance of SOEs in China. The Chinese Economy, 50(1), 21-33. https://doi.org/10.1080/10971475.2016.1211903

Wang, S., Haque, M., \& Lamb, S. (2016). Does transfer of control rights and private benefits of control increase efficiency? Evidence from China's privatization of the SOEs. Journal of Chinese Economic and Business Studies, 4(4), 329-346. https://doi.org/10.1080/14765284.2016.1175766

Xu, X., \& Wang, Y. (1999). Ownership structure and corporate governance in Chinese stock companies. China Economic Review, 10, 75-98. https://doi.org/10.1016/S1043-951X(99)00006-1

\section{Copyrights}

Copyright for this article is retained by the author(s), with first publication rights granted to the journal.

This is an open-access article distributed under the terms and conditions of the Creative Commons Attribution license (http://creativecommons.org/licenses/by/4.0/). 